ROCZNIK PRZEMYSKI t. 57

LITERATURA I JEZYK z. 2 (25) 2021

MICHAL KURAN (Łódź)

ORCID: 0000-0002-0378-2453

\title{
„QUO VADIS?” DWA KAZANIA \\ SEBASTIANA PISKORSKIEGO Z OKAZJI ŚWIĘCEŃ KAPŁAŃSKICH, OBŁÓCZYN I PROFESJI ZAKONNEJ POTOMKÓW FRANCISZKA SZEMBEKA - STRUKTURA I PROBLEMATYKA
}

\author{
Abstract \\ “Quo vadis?" Two sermons by Rev. Sebastian Piskorski on the occasion \\ OF ORDINATION, VESTURE AND TAKING VOWS OF FRANCISZEK SZEMbEK's CHILdREN - \\ THE STRUCTURE AND MAIN ISSUES
}

This study is devoted to two sermons by Rev. Sebastian Piskorski delivered during the ceremonies of the first mass of Michał Szembek and taking the veil and religious vows by Teresa Franciszka Szembekówna, Nun of the Visitation - both children of Franciszek Szembek. The paper analyzes the roles of particular elements of the sermons in creating a persuasive message whose aim is to accompany the young in their rites of passage. The preacher shows them what the way they have chosen will look like. He makes them realize the significance of the mission they undertake as well as possible difficulties; he introduces them into the special nature of the clergy, showing them what they give up and what they let themselves in for. Those deliberations, referring to the motifs of mystical meal and mystical way, are supposed to assist them in making a free and conscious decision. What is remarkable is the exceptional skill of the preacher, who has based his discussion on Gospel pericopes devoted to certain days of the liturgical calendar. The invention base for the sermons is the Bible and the writings of the Church Fathers. What is also important is estate-related factors: the significance and consequences of the vows taken and the mission Michał and Teresa Franciszka are to undertake once they become part of the clergy. Time showed that it was particularly Teresa Szembekówna that fulfilled her task, as a promoter of the worship of the Heart of Jesus in Poland; her zeal contributed to Pope Clement XIII sanctioning the worship.

Keywords: Sebastian Piskorski, Franciszek Szembek, Michał Szembek, Teresa Szembekówna, sermon at taking religious vows, sermon at First Mass

Słowa kluczowe: Sebastian Piskorski, Franciszek Szembek, Michał Szembek, Teresa Szembekówna, kazanie podczas obłóczyn i profesji zakonnej, kazanie na prymicjach

Sebastian Piskorski (1636-1707), rektor Akademii Krakowskiej w latach 1693-1699, prawnik i architekt, a także poeta, tłumacz, hagiograf i kaznodzieja 
(święcenia przyjął w roku 1676), archidiakon kolegiaty Wszystkich Świętych w Krakowie ${ }^{1}$, zarazem kanonik wieluński, uprawiał bogatą i zróżnicowaną twórczość literacką w języku łacińskim i polskim obejmującą około 27 publikacji². Był najpierw wykładowcą poetyki i retoryki w Szkołach Nowodworskich, dyrektorem ${ }^{3}$ i profesorem prawa w Akademii Lubrańskiego, potem objął katedrę prawa kanonicznego i cywilnego w Akademii Krakowskiej, następnie w latach 1693-1699 sprawował sześciokrotnie urząd rektora tej uczelni. Związany był między innymi z rodem Szembeków - pracował jako nauczyciel domowy Stanisława Szembeka, jego braci Przecława i Aleksandra 4 .

Na dokonania literackie Piskorskiego składa się poezja okolicznościowa związana z życiem akademickim (Virens laureum; Auspicium [...] in rectorum renuntiatione), pisana ku czci dostojników kościelnych (biskupów Mikołaja Oborskiego i Stefana Wierzbowskiego), dzieła prawnicze (m.in. Quaestio iuridica de foro et poenis saecularium in criminibus mixti foiri...), twórczość kaznodziejska, utwory uświetniające uroczystości rodzin szlacheckich i pisarstwo dewocyjne. Przetłumaczył także Żywoty Ojców abo Dzieje i duchowne powieści starców, zakonników, pustelników wschodnich... ${ }^{5}$. Okolicznościowe publikacje Piskorskiego były bogato ilustrowane, zwłaszcza te poświęcone św. Salomei: Flores vitae b[eatae] Salomeae virginis / Kwiecie żywota b[togosławionej] Salomei panny (Kraków 1661) też kazanie z okazji beatyfikacji Kunegundy, fundatorki klarysek w Starym Sączu, pt. Błogostawiona Kunegunda panna... (Kraków 1684)7.

${ }^{1} \mathrm{Na}$ temat funkcji związanych z nieistniejącą już kolegiatą Wszystkich Świętych w Krakowie zob. B. Szady, Prałatury i kanonie Kolegiaty Wszystkich Swiętych w Krakowie w II połowie XVIII wieku, „Archiwa, Biblioteki i Muzea Kościelne” 2006, t. 86, s. 331-354.

${ }^{2}$ W. Baczkowska, Piskorski Sebastian Jan, [w:] Polski słownik biograficzny, t. 26, Wrocław 1981, s. 559; K. Estreicher, Bibliografia polska, t. 24, Kraków 1912, s. 319-328.

${ }^{3} \mathrm{O}$ statusie dyrektora w koloniach Akademii Krakowskiej zob. Z. Ruta, Nauczyciele kolonii akademickich Uniwersytetu Krakowskiego w XVIII wieku, ,Rocznik Naukowo-Dydaktyczny WSP w Krakowie" 1968, z. 32: Prace Historycznoliterackie 4, s. 95-167.

${ }^{4}$ B. Natoński SJ, Piskorski Sebastian, [w:] Stownik polskich teologów katolickich, red. H.E. Wyczawski, t. 3, Warszawa 1982, s. 373; W. Baczkowska, dz. cyt., s. 559.

${ }^{5}$ W. Baczkowska, dz. cyt., s. 560.

${ }^{6} \mathrm{O}$ związkach słowa i obrazu w dziełach Piskorskiego zob. m.in.: J. Pelc, Stowo i obraz na pograniczu literatury i sztuk plastycznych, Kraków 2002, s. 338-341; A. Kozak, Zwiąki literacko-obrazowe w utworze S. Piskorskiego „Flores Vitae B. Salomeae”, [w:] Stowo i obraz. Materiaty Sympozjum Komitetu Nauk o Sztuce Polskiej Akademii Nauk, Nieborów, 29 września - 1 października 1977 r., red. A. Morawińska, Warszawa 1982, s. 126; R. Grześkowiak, J. Niedźwiedź, Nieznane polskie subskrypcje do emblematów religijnych Ottona van Veen i Hermana Hugona. Przyczynek do funkcjonowania zachodniej grafiki religijnej w kulturze staropolskiej, „Terminus” 2012, z. 1, s. 47-68. Zob. też M. Kurzej, Ksiadz Sebastian Piskorski a sztuka i historia, [w:] Sztuka po Trydencie, red. K. Kuczman, ks. A. Witko, Kraków 2014, s. 415-428; idem, ,, Generosa proles Almae Parentis Sarmaticae". Ryciny alegoryczne w zbiorach stemmatów ku czci nowych doktorów Uniwersytetu Jagiellońskiego, [w:] „, Velis quod possis”. Studia z historii sztuki ofiarowane profesorowi Janowi Ostrowskiemu, red. A. Betlej et al., Kraków 2016, s. 303-309.

${ }^{7}$ Zob. J. Gwioździk, Kultura pisma i książki w żeńskich klasztorach dawnej Rzeczypospolitej XVI-XVIII wieku, Katowice 2015, s. 443-444. 
Piskorski publikował także kazania pogrzebowe. Na przykład w roku 1699 żegnał biskupa krakowskiego Jana Małachowskiego (Kazanie na pogrzebie [...]. W kościele katedralnym krakowskim ..., Kraków 1699). Najobszerniejszym bodajże dziełem księdza rektora są podzielone na trzy części Kazania na dni Pańskie, na uroczystości Bogarodzice Panny Niepokalanie Poczętej, na święta osobliwe stug Pańskich (Kraków 1706, całość liczy 1048 stron). Utwór stanowi sumę doświadczeń kaznodziejskich Piskorskiego. Ciekawą inicjatywą jest zbiór pt. Regia solis, sublimibus alta columnis Alma Studii Generalis Craciviensis... (Cracoviae 1702) gromadzący mowy ku czci świętych pańskich oraz dawnych krakowskich i poznańskich dostojników kościelnych, a także ludzi zasłużonych w dziejach (np. Piotra Tomickiego, Bernarda Maciejowskiego, Jana Długosza, Bartłomieja Nowodworskiego), wygłoszone przez wypromowanych na krakowskiej uczelni doktorów ${ }^{8}$.

Ważną postacią z perspektywy kazań Wesołe uraczenie Chrystusa... i Quo vadis ... jest Franciszek Szembek (zm. 1693), ojciec przyjmującego święcenia Michała Onufrego oraz przyoblekającej habit wizytki Teresy, a w zakonie Franciszki. Ich matką była pierwsza żona Franciszka, Zofia Pieniążkówna. Zauważyć należy, iż nie tylko te jego dzieci podążyły drogą życia konsekrowanego. Spośród rodzeństwa biologicznego również Antoni został kanonikiem przemyskim, Ewa Rozalia (w zakonie Cecylia Mariancylla od Trójcy Świętej) została karmelitanką bosą, zaś syn Stanisław (1650-1721) biskupem włocławskim, potem gnieźnieńskim i prymasem Polski ${ }^{9}$. Również należący do przyrodniego rodzeństwa po drugiej żonie Annie Barbarze Rupnikowskiej bracia obrali stan duchowny: Ludwik został kanonikiem krakowskim, natomiast Krzysztof Andrzej biskupem warmińskim i sekretarzem wielkim koronnym ${ }^{10}$. Zarówno bohaterka kazań Piskorskiego Franciszka, jak i jej siostra Cecylia Mariancylla od Trójcy Świętej pozostawiły po sobie pewien dorobek literacki ${ }^{11}$.

Przyczyn tak licznych powołań wśród potomstwa Franciszka Szembeka można doszukiwać się nie tylko w dążeniu do zachowania dopiero co zyskanego

\footnotetext{
${ }^{8}$ B. Natoński SJ, Piskorski Sebastian, op. cit., s. 374.

${ }^{9}$ Zob. A. Link-Lenczowski, Szembek Stanistaw, [w:] Polski stownik biograficzny, t. 48, Warszawa-Kraków 2012-2013, s. 115-122.

${ }^{10}$ T. Oracki, Stownik biograficzny Warmii, Prus Ksiażęcych i Ziemi Malborskiej od połowy XV do końca XVIII wieku, t. 2: L-Z, Olsztyn 1988, s. 198; P. Nitecki, Biskupi Kościoła w Polsce w latach 965-1999. Stownik biograficzny, przedm. H. Gulbinowicz, Warszawa 2000, s. 431.

${ }^{11}$ Cecylia Mariancylla od Trójcy Świętej (zm. 26 I 1701) pisała w krakowskim klasztorze św. Marcina modlitwy i teksty ascetyczne zebrane w rękopiśmiennej Książe różnych nabożeństw i modlitw, i nauk (zob. M. Sokalski, Szembek Franciszek, [w:] Polski stownik biograficzny, op. cit., t. 48, s. 45). Z kolei Franciszka Szembekówna opublikowała anonimowo dzieła służące krzewieniu kultu Serca Jezusowego: broszurę Do osobliwych zelatorów Najsłodszego Serca Jezusowego Braci i Sióstr tej Kongregacyi (Kraków 1718), modlitewnik Raj niebieski Najsłodsze Serce Jezusa (Kraków 1718, 1725) oraz rozmyślania Waga miłości Pana Jezusa ku ludzkiemu narodowi (Kraków 1719) (zob. J. Daranowska-Łukaszewska, Szembekówna Teresa, [w:] Polski stownik biograficzny, op. cit., t. 48, s. 126; M. Borkowska, Leksykon zakonnic polskich epoki przedrozbiorowej, t. 2: Polska Centralna i Poludniowa, Warszawa 2005, s. 314).
} 
miejsca rodu wśród elity magnackiej Rzeczypospolitej, lecz również w środowisku duchowieństwa, z jakim Szembek utrzymywał bliskie stosunki. Jako starosta biecki w latach 1667-1681 pozostawał w doskonałych relacjach z tamtejszymi reformatami. Udzielał też wsparcia zakonnikom w ich staraniach o pozyskanie placu pod budowę kościoła i klasztoru w obrębie murów miejskich stołecznego miasta Krakowa ${ }^{12}$. Godna odnotowania jest ponadto oda Piskorskiego, jaką napisał ku czci Franciszka Szembeka w podziękowaniu za ufundowanie kościoła reformackiego w Krakowie pw. św. Kazimierza: Basilicus iactus in primi lapidis positione... z $1666 \mathrm{rr}^{13}$

Okolicznościowa twórczość towarzysząca obłóczynom, składaniu profesji zakonnej i odprawianiu mszy prymicyjnych nie doczekała się kompleksowych badań. Zwracają uwagę prace poświęcone kształtowi ideału życia zakonnego w Kościele po Soborze Trydenckim ${ }^{14}$, świeckim mowom obłóczynowym ${ }^{15}$ i poezji towarzyszącej składaniu ślubów zakonnych ${ }^{16}$. W niewielkim stopniu przebadano kazania towarzyszące obłóczynom, profesji zakonnej i prymicjom ${ }^{17}$.

${ }^{12}$ M. Sokalski, Szembek Franciszek, op. cit., s. 45; J. Pasiecznik, Kościót i klasztor reformatów w Krakowie, Kraków 1978, s. 62, 69, 72.

${ }^{13}$ Dostępne online: https://polona.pl/item/basilicvs-iactvs-in-primi-lapidis-positione-dvmfranciscvs-in-slvpow-szembek,MjY2MDgxOTA/4/\#item [dostęp: 15 V 2021].

${ }^{14} \mathrm{H}$. Wojtyska, Potrydenckie przemiany $w$ koncepcji żeńskiego życia zakonnego, „Studia Warmińskie" 2001, t. 38, s. 179-184; B. Puchalska-Dąbrowska, Potrydencki ideat życia zakonnego na przykładzie staropolskich żywotów św. Teresy od Jezusa, „Rocznik Teologii Katolickiej” 2015, t. $14 / 1$, s. $177-191$.

${ }^{15}$ M. Trębska, Świeckie mowy obłóczynowe a ceremoniały zakonne w XVII wieku, „Napis” 2010, t. 1(16), s. 123-137; eadem, ,, Odważna Judyt” i mężna ,, w Bogu Amazonka”, czyli o walce duchowej w staropolskich oracjach obłóczynowych, [w:] Wojny, bitwy, potyczki w kulturze staropolskiej, red. W. Pawlak, M. Piskała, Warszawa 2011, s. 373-386.

${ }^{16}$ K. Kaczor-Scheitler, ,, Wieniec białoczerwony lilijowy...”. Staropolskie epitalamium nabożne Stanistawa Teodora Piotrkowczyka, [w:] „Fons omnis honesti”. O literaturze w stużbie wartości: tradycja antyczna, kultura ziemiańska, encyklopedyzm i komunikacja. Studia ofiarowane Profesor Marii Wichowej w 70. rocznice urodzin i 45. rocznice pracy naukowej i dydaktycznej, red. M. Kuran, Łódź 2020 („Analecta Literackie i Językowe”, t. 14), s. 181-197.

${ }^{17}$ Zob. J. Gwioździk, op. cit.; M. Kuran, Kazania upamiętniające przyjęcie święceń duchownych przez synów i córki szlachty zwiazanej ze Wschowa (wybrane przykłady z rodzin Gurowskich i Mycielskich), [w:] Rycerze - szlachta - ziemianie. Szlachetnie urodzeni na ziemi wschowskiej i pograniczu wielkopolsko-ślaskim, red. P. Klint, M. Małkus, K. Szymańska, Wschowa-Leszno 2014, s. 315-332; idem, Tryumf Taidy ogłoszony. O diariuszu obłóczyn u dominikanek lwowskich księżnej Teofili Wiśniowieckiej w 1753 roku, „Tematy i Konteksty” 2014, nr 4(9): Piśmiennictwo zakonne, s. 269-291; idem, Kazanie na mszy prymicyjnej Józefa Bernarda Gurowskiego opata przemęckiego - ku chwale rodu, w stużbie ojczyźnie $i$ Kościołowi, [w:] Reformacja i tolerancja. Jedność w różnorodności? Wspótistnienie różnych wyznań na ziemi wschowskiej i pograniczu wielkopolsko-śląskim, red. M. Małkus, K. Szymańska, Wschowa-Leszno 2015, s. 319-336; idem, Drukowane oracje na obłóczyny i profesje zakonne dominikanek lwowskich w XVIII w. - adresatki, autorzy, walory literackie, funkcje spoleczne i kulturowe, [w:] „,Arma nostrae militiae”. Kultura ksiązki i pisma Zakonu Kaznodziejskiego na ziemiach polskich, red. I. Pietrzkiewicz, M. Miławicki OP, Poznań 2019 („Studia i Źródła Dominikańskiego Instytutu Historycznego w Krakowie”, t. 20), s. 313-334. 
Wśród nielicznych utworów napisanych w języku polskim uwagę zwracają wydane razem dwa kazania poświęcone obierającym życie duchowne przedstawicielom rodu Szembeków, córce i synowi Franciszka Szembeka. Pierwsze z nich, opatrzone datą 1686, upamiętnia przyjęcie święceń kapłańskich przez kanonika przemyskiego Michała Szembeka i jednocześnie szaty zakonnej przez jego siostrę Teresę Szembekównę, drugie kazanie, wydane rok później, poświęcone jest złożeniu wieczystej profesji zakonnej przez obłóczoną rok wcześniej Teresę, która przyjęła imię zakonne Franciszka. Zwraca uwagę upamiętnienie podczas jednej uroczystości prymicji i obłóczyn, jak też łączna publikacja kazań obłóczynowego i z okazji profesji zakonnej wygłoszonych przez jednego mówcę. Kazania warte są też oglądu ze względu na interesujący program tematyczny, w którym oś stanowią motywy pokarmu i drogi ukazane w kontekście ofiary oraz dążenia do mistycznego zjednoczenia z Chrystusem. Warto poświęcić uwagę tym oracjom również dlatego, że sytuują się u początku drogi Teresy Szembekówny - jednej z największych propagatorek kultu Serca Jezusowego w Polsce. Jej starania o zatwierdzenie tego kultu przez papieża Klemensa XIII zostały zwieńczone sukcesem. Stało się tak dzięki krewnym i możnym, którzy udzielili zakonnicy wsparcia $^{18}$. Kazania utrwalają program duchowości i atmosferę, w jakiej rozwijało się powołanie siostry Teresy w początkach jej zakonnego życia.

Godny uwagi jest program tematyczny kazań oparty na symbolice wywodzącej się z Biblii oraz z nauczania Ojców Kościoła. Teksty te stanowią retoryczne zaplecze dla perswazji (wyrażanej formułowaniem zachęt do dobrowolnego obioru drogi życia konsekrowanego), jaka towarzyszy temu rytuałowi przejścia ${ }^{19}$. Kaznodzieja pokazuje związek przyszłego życia konkretnych osób z uznanymi za modelowe czynami i losami postaci biblijnych.

Kazania ${ }^{20}$ poprzedza łaciński cytat z Księgi Izajasza: „Dabo eis in domo mea et in muris meis locum et nomen melius a filiis et filiabus, nomen sempiternum dabo

\footnotetext{
${ }^{18}$ C. Drążek SJ, Rozwój kultu Serca Jezusa w Polsce, [w:] Bóg bliski. Historia i teologia kultu Najświętszego Serca Jezusa. Praca zbiorowa, red. C. Drążek, L. Grzebień, Kraków 1984, s. 60, 78-80, 93.

${ }^{19}$ Zob. M. Trębska, Świeckie mowy obłóczynowe..., s. 137.

${ }^{20}$ Wszystkie cytaty podaję za edycją: S. Piskorski, Wesołe uraczenie Chrystusa. Sztuka ryby pieczonej i plastr miodu. Pierwsza ofiara Pańska W[ielebnego] J[ego] M[ości] Ks[iędza] Michała z Stupowa Szembeka, kanonika przemyskiego, i przyjęciem habitu zakonnego W[ielmożnej] Jej M[o]ści Panny Teresy z Stupowa Szembekówny, kasztelan[iców] sanockich w klasztorze W[ielebnych] Panien Zakonnych Nawiedzenia Naświętszej Matki Boskiej przy Krakowie $w$ dzień wtorkowy wielkanocny..., i dołączonymi do niego z osobną kartą tytułową Quo vadis albo Kazanie przy profesyjej ślubów zakonnych Wielmożnej Jej Mości Panny Teresy z Stupowa Szembekówny, kasztelanki sanockiej, a teraz Wielebnej w Chrystusie Panu siostry Franciszki, w konwencie W[ielebnych] Panien Zakonnych Nawiedzenia Najświętszej Matki Boskiej przy Krakowie. W niedzielę czwarta po Wielkiejnocy, Kraków 1686 [wyd. po 20 IV 1687]. Cytaty z kazania Wesołe uraczenie oznaczam literą W, natomiast z Quo vadis ... - Q, dopełniając numerem karty.
} 
eis, quod non peribit”21 (Iz 56,5). Powołanie się na te słowa ujawnia już na wstępie dowodową sprawność kaznodziei, który stawia przed przedstawicielami rodu Szembeków podejmującymi życiowe decyzje atrakcyjne dary w postaci lepszego niż zwyczajne, ludzkie mieszkania i życia. Wykraczają one oczywiście poza perspektywę doczesną, wyłączają obdarowanych z przestrzeni tradycyjnej doczesności z domem, dziećmi, majętnością i społecznym zaangażowaniem na rzecz ojczyzny. Poszerzają horyzont, otwierając oczy na sferę duchową. To jej podporządkowane ma być działanie wyświęcanego księdza i młodej zakonnicy. Cytat z Księgi Izajasza nakreśla kompletną wizję całego przyszłego życia: schronienie w domu za murem bez córek i synów, za to z obietnicą przekroczenia granicy śmierci w sferze cielesnej.

Kolejne cytaty-motta inicjujące dwa następujące po sobie kazania nie mają jednorodnego charakteru. Pierwsze, z Ewangelii św. Łukasza, mówi o objawieniu się zmartwychwstałego Chrystusa apostołom: „Stetit Iesus in medio discipulorum suorum, et dicit eis: Pax Vobis. Habetis hic aliquid, quod manducetur? At illi obtulerunt ei partem piscis assi et favum mellis. Sumens reliquias dedit eis"22. Słowa z tego cytatu budują tytuł kazania poprzez skojarzenie uczty eucharystycznej i zarazem mszy prymicyjnej Michała Szembeka z posiłkiem, jaki spożył Chrystus wśród apostołów. Kluczowym stał się pokarm i napój: ryba i miód symbolizujące tu obfitość i sytość. Drugie z kazań opatrzone zostało mottem z Ewangelii Janowej: „Vado ad eum, qui misit me, et nemo ex vobis interrogat me, quo vadis? Joan 16. Idę do tego, który mnie posłał, a żaden $\mathrm{z}$ was nie pyta mnie, gdzie idziesz?" (J 16,5b). Kaznodzieja zwraca uwagę na motyw drogi, wyprawy do niebiańskiego źródła misji, usytuowanego poza doczesnymi realiami. Analogicznie jak w przypadku pierwszego tekstu orator wydobywa z cytatu słowa, które umieszcza $\mathrm{w}$ tytule jako stanowiące myśl przewodnią: „Quo vadis?”. Wspólnym punktem kazań są więc motywy wieczerzy, posilania ciała oraz drogi, czyli wędrówki mającej objąć całe życie doczesne i wieczne zakonnicy składającej śluby wieczyste.

Pierwszy z tekstów budzi zainteresowanie, ponieważ łączy konwencję kazania obłóczynowego i wygłoszonego z okazji przyjęcia święceń kapłańskich. Piskorski ujmuje prostotą tytułu: Wesołe uraczenie Chrystusa. Sztuka ryby pieczonej i plastr miodu. Odwołuje się do pokarmów, jakie otrzymał zmartwychwstały Chrystus podczas nawiedzenia uczniów w Wieczerniku, gdy poprosił o coś do jedzenia (Łk 24,41-43). Tytuł drugiego z kazań, jak wspomniano, otwierają słowa: „Quo

${ }^{21}$ „Dam im w domu moim i w murzech moich miejsce i imię lepsze nad syny i córki. Imię wieczne dam im, które nie zaginie", cyt. za: Biblia w przekładzie księdza Jakuba Wujka z 1599 r., transkrypcja typu „B” oryginalnego tekstu z XVI w. i wstępy ks. J. Frankowski, wyd. 3, Warszawa 2000. Wszystkie cytaty biblijne podaję za tym wydaniem.

${ }^{22}$ Łk 24,36, 41-43: ,[...] stanął Jezus w pośrzodku ich i rzekł im: «Pokój wam: jam jest, nie bójcie się». [...] «Macie tu co jeść?» A oni mu dali sztukę ryby pieczonej i plastr miodu. [...] Wziąwszy ostatki, dał im”. 
vadis" (J 16,5). Zostały one wydobyte z miejsca w Ewangelii św. Jana, w którym Jezus zapowiada uczniom, że będą z powodu wiary w niego doznawać prześladowań, cierpieć. Obwieszcza im też, że opuszcza ziemię, by udać się do Boga. Chrystus wypomina uczniom brak pytania o to, dokąd się udaje. On, a za nim kaznodzieja uznaje to pytanie za fundamentalne. Poza przesłaniem sformułowanym w tytułach kazań istotny wydaje się moment ich wygłoszenia. Piskorski w obu przypadkach nie podaje daty dziennej, natomiast osadza kazania w kalendarzu roku liturgicznego. Pierwszego z nich wysłuchano we wtorek po Wielkanocy, zaś drugiego rok później w czwartą niedzielę po Wielkanocy. Stanowiące podstawę rozważań motta zaczerpnięte zostały z czytań przeznaczonych na dany dzieńn ${ }^{23}$.

Wiodącym słowem we wstępie pierwszego z kazań stał się czasownik ,stawa”. Piskorski wiąże je z postawą Chrystusa tryumfującego, dobrego pasterza i ojca. Celem mówcy staje się „ocieplenie” wizerunku Jezusa poprzez ukazanie jego miłosnej relacji z najbliższymi, przypominającej związek pasterza z owcami, ojca z dziećmi. „Stanie” kojarzy kościelny orator z vita activa, którą postrzega jako misję pośredniczenia między Bogiem a ludźmi. Za antynomię stania uważa odpoczywanie, leżenie i próżnowanie. Wedle wizji rzeczywistości kreowanej przez Piskorskiego są one sprzeczne z misją, jaką decydują się podjąć ci, którzy zaciągną się pod chorągiew Chrystusa. Odwołuje się więc do koncepcji znanej z Ćwiczeń duchownych św. Ignacego Loyoli. Postrzega kapłana jako żołnierza. Uznając przestrzeń kościoła za odzwierciedlającą model interpersonalnych relacji, wiąże stanie duchownego ze stallami, a więc przestrzenią pomiędzy sferą boską a zarezerwowaną dla świeckich. Miejsca kapłana nie widzi wśród ludzi, lecz pomiędzy Bogiem a ludźmi. Postrzega duchownego jako przewodnika dusz. Buduje analogię między miejscem Astrei, usytuowanej pomiędzy „odważnym lwem a dobrze rozważną wagą" (W, k. $\mathrm{A}_{2}$ ), i duchownego we wspólnocie ludzkiej. Kapłan jak bogini sprawiedliwości winien stetit in medio.

Kolejny znaczący zwrot wydobyty z motta to „Pokój wam”. Utwierdzając osoby podejmujące życie konsekrowane w powołaniu i przekonaniu o prawidłowym wyborze drogi życiowej, mówca dowodzi, iż w akcie święceń przez ręce biskupa Bóg „ducha spokojnego na kapłany poświęcone wylewa” (W, k. $\left.A_{2} v\right)$. Powraca do obrazu Jezusa jako nauczyciela i ojca troszczącego się o swoich uczniów i dzieci. Piskorski podkreśla, iż pokój płynie z zadowolenia, jakie niesie dobrowolny i trafny wybór drogi życiowej w stanie duchownym. Przekonuje, że jest on darem i dowodem aprobaty Boga.

Kolejną cząstkę rozważań Piskorski rozpoczyna od pytania: „A macież tu co do jedzenia?". Inicjuje tym samym egzegezę dalszego fragmentu cytatu-motta. Przyciąga uwagę odbiorcy, unaoczniając powodujący zdziwienie paradoks. Zaskoczenie wywołuje fakt, iż pan, nauczyciel i ojciec prosi o chleb

${ }^{23}$ Zob. Postylla polska, to jest lekcyje, epistoty i ewanjelije przez caly rok, Kraków 1577, k. $\mathrm{O}_{4}-\mathrm{O}_{5}, \mathrm{P}_{5}-\mathrm{P}_{5}$ v; Missale Romanum, Antverpiae 1634, s. 291. 
swoje sługi, uczniów i dzieci. Konsekwentnie więc już bazuje Piskorski na obrazie Chrystusa jako Pana, nauczyciela, jak też ojca. Odpowiedź twierdząca na wyjściowe pytanie wspiera kaznodzieja cytatem z satyryków rzymskich Persjusza i Juwenalisa: Rara avis in terris - „Rzadki na ziemi ptak”24, dowodząc, iż wyjątkową jest sytuacja, gdy syn karmi ojca, a syn i córka - matkę i ojca. Powołuje się na polskie prawo mówiące, że rodzice nie dziedziczą po dzieciach. Piskorski przekonuje, iż obdarowującymi winni być zawsze rodzice. W ten sposób mówca chce udowodnić, że dzieci nie są zobowiązane do zaspokajania ambicji rodziców. Kaznodzieja nawiązuje tu do ślubów czystości składanych przez osoby obierające życie zakonne i do celibatu przyrzekanego przez duchowieństwo diecezjalne. Ich konsekwencją jest brak zstępnych. Dla społeczeństwa doby staropolskiej przerwanie rodowej sztafety sukcesji (rozumianej jako następstwo pokoleń), obejmującej nie tylko majątek, ale też herb $\mathrm{i}$ inne godności, miało fundamentalne znaczenie. Wybór życia konsekrowanego stanowił dowód poświęcenia dla spraw wyższych tej doczesnej sfery, oznaczał radykalny rozbrat z myśleniem w kategorii rodu: ,[...] idąc za Chrystusem i świata, i rodziców, i braci, i przyjaciół, i samych siebie wieczny wyrok czynią, o żadnych sukcesorach nie myślą" (W, k. A $)$. Mówca podkreśla i uświadamia odbiorcy całkowitą odrębność drogi, na którą wchodzą osoby obierające życie konsekrowane. Zostają one praktycznie wyłączone z obowiązków wobec rodu. Godności kościelne dawały możliwość wpływu na sprawy państwa i zabezpieczenie interesów rodowych w równolegle funkcjonującej sferze duchownej (biskupi, senatorowie, opaci; majątek kościelny).

Pytając, dlaczego uczniowie podali ukazującemu się po zmartwychwstaniu Chrystusowi rybę i miód, chociaż w minionym czasie Paschy pod dostatkiem było chleba i wina, Piskorski dowodzi za św. Augustynem, iż stało się tak z powodu szczególnej, duchowej natury tych wywodzących się z wody pokarmów (ryby i miodu). Woda, wedle symbolicznego wywodu podążającego za tradycją kaznodziei, jawi się tu jako przeciwieństwo ziemi kojarzonej z dopiero co pokonaną za sprawą zmartwychwstania Chrystusa śmiercią. To nad wodą w dobie stworzenia unosić się miał Duch Święty. Stąd też, wedle kaznodziei, pokarm - ryba - pochodzi z wody, zaś miód z rosy implikującej niebiańską słodycz. Symbolicznie wybór tych pokarmów, jawnie skojarzonych tu ze sprawami wyższymi, radykalne odrzucenie tego, co związane jest z ziemią, otwiera drogę do godnego przyjęcia Chrystusa. Duchowny nie zarabia na chleb, pisze Piskorski, lecz ma zostawić wszystko to, co kojarzy się ze sprawami doczesnymi, by „,...] Zbawiciela uraczyć hojnie, uczęstować mile" (W, k. A $\left.\mathrm{A}_{3} \mathrm{v}\right)$.

${ }^{24}$ Dicta. Zbiór tacińskich sentencji, przystów, zwrotów, powiedzeń z indeksem osobowym i tematycznym, zebrał, oprac. i zred. C. Michalunio, Kraków 2005, s. 546. Pełne brzmienie: „Rara avis in terris nigroque simillima cygno” („Persjusz, Saturae I,46; Juwenalis, Saturae VI,165 opisuje idealną narzeczoną bardzo rzadkie zjawisko"). 
Znamienne, iż w rozważaniach tych powołał się mówca na słowa Pieśni nad pieśniami „Fructus eius dulcis gutturi meo”25 (Pnp 2,3). O ich znaczeniu dla charyzmatu wizytek i propagowanych przez nie idei świadczy fakt, że stały się po śmierci św. Małgorzaty Marii Alacoque (1647-1690), propagatorki kultu Serca Jezusowego, elementem oficjum w dzień jej wspomnienia ${ }^{26}$. Po słowach tych odnosi się kaznodzieja do symboliki herbu własnego Szembeków, przedstawiającego dwa kozły przedzielone pasem z trzema różami, stwierdzając: „I kozły między różą paszące zostawić w domu trzeba” (W, k. A $\mathrm{A}_{3}$ ). Zwyczajowo uświadamia przedstawicielom szlachty i magnaterii obierającym życie konsekrowane konieczność formalnego rozstania ze splendorami właściwymi przedstawicielom stanów uprzywilejowanych w Rzeczypospolitej. Herb jawi się jako jedna z oznak wywyższenia, które należy pozostawić przed furtą klasztorną.

Kolejny akapit skierowany jest do ojca, co sygnalizuje Piskorski w marginalium: „Jaśnie W[ielmożny] rodzic Franciszek” (W, k. A v). Kaznodziejską sprawność Piskorskiego zdaje się potwierdzać kolejny obraz, w którym spotykają się pokarm i ofiara. Tę drugą składa Chrystusowi ojciec w postaci oddawanych Bogu dzieci, przyjmujących święcenia i habit. Piskorski kreśli obraz ryby pływającej we łzach i pszczoły zatopionej w miłości Bożej jak w miodzie:

Ofiary sobie dane, potrawy zgotowane Zbawiciel przyjmuje, ale pokarm jego pływająca we łzach jako ryba, w słodyczy miłości boskiej jako w miedzie zatopiona pszczoła. Nawrócona do Boga, na służbę Pańską oddana, obleczona, poświęcona dusza - pokarm najwdzięczniejszy Zbawiciela (W, k. A v).

Fragment ten pełni funkcję konsolacyjną - kaznodzieja pociesza rodziców żegnających dzieci wchodzące na drogę życia duchownego. Piskorski wyjaśnia, jakie jego zdaniem ofiary są Bogu najmilsze. Zalicza do nich łzy wylane przy nawróceniu przez pokutujące dusze. Wzmiankuje pokutujące jawnogrzesznicę i Samarytankę. Osoby te i ich historie stanowią analogię do sytuacji rodziców żegnających dzieci, opłakujących ich odejście od spraw świata. Dlatego sięgnął też mówca do obrazu Hioba, który utracił potomstwo, i ofiary, jaką miał złożyć Abraham z Izaaka. W osobie Franciszka Szembeka, jego postawie i działaniach widzi orator aktualizację biblijnych sytuacji w czasach jemu współczesnych. Kaznodzieja wspomina o dwu synach i dwu córkach ofiarowanych wcześniej przez Szembeka na służbę Kościołowi. Wymienia Stanisława i przyjmującego wówczas święcenia Michała oraz córkę Ewę Rozalię (w zakonie karmelitanek Teresę), jak też przywdziewającą właśnie habit wizytek Teresę (w zakonie Franciszkę).

Adresatami kolejnej cząstki wypowiedzi kaznodziei stało się rodzeństwo wstępujące na drogę życia duchownego porównane do pary synogarlic, które również są

\footnotetext{
${ }^{25},[\ldots]$ owoc jego słodki gardłu memu".

${ }^{26} 17$ października - św. Małgorzaty Marii Alacoque, dziewicy (3 kl., szaty białe). Zob. Bractwo Kaptańskie Świętego Piotra. Duszpasterstwo wiernych Liturgii Łacińskiej. Polska, dostępne online: https://www.fssp.pl/articles/574 [dostęp: 10 V 2021].
} 
postrzegane jako ofiara, potrawa dla Chrystusa, przez analogię do wspomnianych wcześniej ryby i miodu. Mając na uwadze specyfikę drogi powołania i misji Michała Onufrego, Piskorski rozważa tajemnicę ofiary Chrystusa w relacji do ofiary życia składanej przez neoprezbitera. Mówca powołuje się na słowa z Ewangelii św. Jana: „Mój pokarm jest, abych czynił wolą tego, który mię posłał, abych wykonał sprawę jego" (J 4,34), i na św. Augustyna wzywanego do osiągnięcia dojrzałości: „Jestem pokarmem dla dorosłych. Dorośnij, a będziesz mnie pożywał. I nie zmienisz mnie w sobie jako pokarm dla swego ciała, ale sam się zmienisz we mnie" 27 . Rozwijając rozumowanie Augustyna, stwierdza Piskorski w ślad za św. Hieronimem: „Chrystus samże bankietuje, sam jest i bankietem, sam zażywającym i sam zażywanym” (W, k. A ${ }_{4}$ r). Kaznodzieja uświadamia więc konieczność wewnętrznej integracji duchownego z Chrystusem, w którego imieniu kapłan ma pełnić swoje obowiązki. Podkreśla konieczność podjęcia dojrzałej decyzji, by wziąć udział w tej misji. W duchu mistycyzmu wskazuje konieczność wewnętrznej przemiany, poświęcenia swoich spraw, by stać się jak Chrystus, dać siebie za pokarm innym (poświęcając się służbie) i spożywać go - w sensie duchowym.

Zwracając się do przyjmującej habit Szembekówny, odwołał się Piskorski do topiki oblubieńca i oblubienicy wywiedzionej z Pieśni nad pieśniami. I znowu chodzi o duchowe zjednoczenie Chrystusa i duszy, tym razem duszy zakonnicy. Panny, poprzez nawiązanie do ich seksualnej wstrzemięźliwości oznaczającej czystość, utożsamione zostały z liliami, które stały się ich symbolem. Integracja duszy z Chrystusem dokonuje się, wedle kaznodziei, w trojaki sposób: w formie pełnego oddania ducha niebiańskiemu oblubieńcowi, poprzez spożywanie danego przez niego pokarmu i poprzez stanie się pokarmem dla Baranka-Oblubieńca. Relację duszy i Chrystusa opisał Piskorski, czerpiąc z topiki biblijnej: lilia oznacza czystość, baranek ofiarę, pasienie się uobecnia zarazem akt posilania duszy, jak i proces trwania $\mathrm{w}$ jedności i spalania się w miłości do oblubieńca. Dowodami oddania wiodącego ku zjednoczeniu jest spełnienie warunków związanych z drugim punktem - pobożnym życiem, które wyraża się: ,[...] dobremi postępkami naszemi, pokarm jego pokuta moja, pasza jego zbawienie moje, napój jego posilenie jego - nawrócenie moje, łzy moje" (W, k. [ $\left.\left.\mathrm{A}_{4}\right]\right)$. Ich spełnienie otwiera drogę do mistycznej wspólnoty duszy z Chrystusem-Barankiem, który „pasie się” - jak rzecz ujmuje Pieśń nad pieśniami, przywołana kilkakrotnie w omawianej cząstce tekstu - „Qui pascitur inter lilia” (Pnp 2,16; W, k. A v). Wzorem postawy wyrażającej oddanie i bliskość z Jezusem stał się św. Jan, który miał zasnąć na piersiach Chrystusa (J 13,25: „Itaque cum recubuisset ille supra pectus Jesu, dicit ei: Domine quis est? - On tedy położywszy się na piersiach Jezusowych, rzekł mu: Panie, kto jest?”, W, k. A 4 v). Fizyczna bliskość stać się miała wedle Piskorskiego, podążającego za tradycją, źródłem onirycznej iluminacji apostoła, którego małe ,ja" zostało zastąpione przez „Ja” Chrystusowe, co dowodzi duchowej jedności (taki

\footnotetext{
${ }^{27}$ Św. Augustyn, Wyznania, tłum. S. Stabryła, Kraków 2020, ks. VII,10, s. 184.
} 
sens przedstawia też obraz Jacopa Bassano Ostatnia Wieczerza z 1546 r.). Przez analogię również mistyczne zjednoczenie duszy z Barankiem-Oblubieńcem jest odpowiednikiem tamtej bliskości (Jana i Jezusa), która realizować się ma podczas ofiary eucharystycznej (analogicznie do Ostatniej Wieczerzy), otwierając czystym duszom drogę do grona błogosławionych.

Piskorski podejmuje następnie kwestię mistycznego zjednoczenia ludzkiej duszy z Bogiem, kierując się słowami Pierwszego Listu do Koryntian: „Qui adhaeret Deo, unus spiritus est. Kto się z Bogiem zjednoczy, jedenże z Bogiem duch jest" (1 Kor 6,17; W, k. A v ). Jedność tę dokumentuje również, przywołując cytat z Listu do Rzymian (Rz 5,5), jak i słowa św. Augustyna mówiące o jedności Trójcy Świętej (,Tria haec unum omnia propter Patrem, aequalia propter Filium, conexa propter Spiritum Sanctum"28; W, k. A v). Mówca dowodzi szczególnej jedności z Bogiem osoby, która weszła na drogę życia konsekrowanego, ukazuje miłość ku Bogu jako efekt działania Ducha Świętego, przekonuje, iż osoba konsekrowana jest ze Stwórcą jednego Ducha („Unus Spiritus est”, 1 Kor 6,17), czyli pozostaje z Nim w mentalnej jedności. Przywołane w tej partii tekstu fragmenty Biblii ukazują jedność człowieka z Bogiem w opozycji do rozwiązłości cielesnej, tożsamej z grzechem oddzielającym od Stwórcy. Kaznodzieja sugeruje, że dokonywany przez wyświęcanych wybór oznacza poniechanie czynności służących zaspokajaniu seksualnego popędu, który ma być zastąpiony miłosnym zjednoczeniem z niebiańskim Oblubieńcem.

Ostatni akapit kazania wiązać należy z należącymi tak do obrzędowości świeckiej, jak i zakonnej przenosinami. Wezwanie z Apokalipsy („Spiritus et Sponsa dicunt: veni", Ap 22,17) stanowi swego rodzaju captatio benevolentiae, zachętę do ostatecznego wyboru drogi, wykonania aktu woli. Powraca motyw pokarmu wyświęcani znowu jawią się jako posiłek dla Chrystusa, ofiara składana Bogu. Zarazem Piskorski słowami psalmisty zaprasza ich do spożywania słodkich dóbr Pańskich: „Pódźcie, gustate et videte, quoniam suavis est Dominus” (Ps 33,9; W, k. B).

Kończące duchowną orację słowa łączą pochwałę matki, Zofii Pieniążkówny, z laudacją prymicjanta. Kaznodzieja wspomina o symbolice barw towarzyszących liturgii, wiążąc ją z kolorami, jakie oferuje rodzima natura. Mowa o jego hiacyntowej (fioletowej) szacie spotykanej w liturgii katolickiej w okresie Wielkiego Postu, choć kazanie zostało wygłoszone we wtorek po Wielkanocy. W tym przypadku kolor ten należy jednak kojarzyć nie z okresem liturgicznym, lecz, jak chce Piskorski, z ,najwyższego kapłana szatą” (W, k. B), a więc z Chrystusem cierpiącym, okrytym purpurowym (fioletowym) płaszczem. Szata owa stanowi, jak dowodzi mówca, dar matki utkany z polskich polnych kwiatów.

\footnotetext{
${ }^{28},[\ldots]$ Trzej razem stanowią jedność ze względu na Ojca, równość ze względu na Syna, zjednoczenie harmonijne wszystkiego przez Ducha Świętego", cyt. za: św. Augustyn, De doctrina christiana. O nauce chrześcijańskiej, wstęp i koment. J. Sulowski, Warszawa 1989, ks. I,12, s. 15.
} 
Uwagę zwraca osobisty ton konkluzji oracji. Zbliżona jest ona formą do pożegnań wypowiadanych przez duchownego w kazaniach pogrzebowych ${ }^{29}$, mimo że tutaj skierowane zostały do osób wchodzących na nową drogę życia. Piskorski wzywa Michała Szembeka do podjęcia ofiarnej posługi, która ma wpłynąć na losy jego najbliższych:

Pódźże kapłanie w hijacyntowej najwyższego kapłana szacie, którąć matka twoja z polskich hijacyntów przywdziała. Miasto kozła z Aaronem immolabit haedum, ofiaruj z Chrystusem tę pierwszą ofiarę Baranka po śmierci swojej żyjącego. Oddaj błagalnią Bogu za Kościół święty, za ojczyznę miłą, za wszytkich twoich. Rzecz nam imieniem Chrystusowym: Pax Vobis (W, k. B).

Mówca zachęca, by za sprawą modlitwy nowo wyświęcony kapłan wzmógł powołanie swej siostry przyjmującej strój zakonny. Michał Szembek był już wszakże osobą konsekrowaną, natomiast jego siostra, przywdziewając habit, w istocie rozpoczynała okres przygotowania do profesji wieczystej. Stąd słowa zachęty kaznodziei skierowane do duchownego, odwołujące się do jego patrona św. Michała Archanioła: „Przy tej ofierze twojej Aniele Boży Quis ut Deus? [podkr. M.K.] Strzałę miłości Boskiej nade wszystko pałającej utkwij w sercu Teresy, siostry, współprymicyjantki twojej”"30 (W, k. B).

Piskorski zwraca się również do biskupa Mikołaja Oborskiego z prośbą o dopełnienie obrzędu zaślubin panny z Bogiem. Odwołuje się przy tym do topiki architektonicznej i florystycznej, a także nawiązuje do motywu wirydarza klasztornego: „A ty, kolumno Kościoła Bożego, lilijo niewinności duchownej, wyrwaną $\mathrm{z}$ między ciernia światowego przesadź w ten ogród lilijowy tę różą pestańskąą, różą hymecką ${ }^{32}$ na chwałę Boga i Matki Jego" (W, k. B). Lilia symbolizuje biskupa, natomiast róża, implikująca piękno i słodycz, prymicjantkę.

W marginalium ujawnia Piskorski udział w obłóczynach jeszcze jednego duchownego: „J[ego] M[iłość] k[siądz] Mikołaj Oborski B[iskup] L[aodycejski],

${ }^{29}$ Zob. M. Kuran, Konwencja pożegnania osoby zmarłej z żywymi w staropolskich kazaniach pogrzebowych - model i jego modyfikacje, [w:] Dawna i wspótczesna kultura funeralna, red. I. Steczko, R. Dźwigoł, Kraków 2018 („Dialog z Tradycją”, t. 6), s. 325-354.

${ }^{30}$ Aluzja do Kanonu rzymskiego: „Supplices te rogamus, omnipotens Deus; iube haec perferri per manus sancti Angeli tui in sublime altare tuum, in conspectu divinae majestatis tuae. Pokornie Cię błagamy, wszechmogący Boże, rozkaż, by ręce świętego Anioła Twego zaniosły tę Ofiarę na niebiański Twój ołtarz, przed oblicze Boskiego Majestatu Twego". Za wskazanie tej aluzji dziękuję recenzentowi tekstu, dr. hab. Wiesławowi Pawlakowi, prof. KUL.

${ }^{31}$ Czyli pochodzącą, jak pisze Roman Krzywy ,z różanych ogrodów Paestum, starożytnej Posejdonii, miejscowości w południowej Kalabrii, słynącej z uprawy róż, które zakwitały tu dwa razy do roku" (R. Krzywy, Komentarze, [w:] S. Twardowski, Władysław IV, król polski i szwedzki, wyd. R. Krzywy, Warszawa 2012 („Biblioteka Pisarzy Staropolskich”, t. 40), s. 385; zob. też idem, Pestańskie róże i równe szczęście. Rozważania na temat objaśnień do tekstu staropolskiego, „Terminus" 2007, z. 2(17), s. 9-10.

${ }^{32}$ Pochodzącą z pasma górskiego Hymet w Attyce, z krainy słynącej z doskonałych miodów. 
suf[ragan] i sch[olastyk] krak[owski], welum oddał". Oborski (1611-1689) $)^{33}$ był krakowskim biskupem pomocniczym zasłużonym dla rozwoju diecezji między innymi jako uczestnik procesów beatyfikacyjnych Szymona z Lipnicy i Mistrza Wincentego tzw. Kadłubka ${ }^{34}$.

Od rozważań o mistycznym zjednoczeniu duszy z Bogiem zmierza mówca do wizji konkretnej posługi wstępujących na drogę życia konsekrowanego. Ksiądz jawi się jako człowiek poświęcający się medytacji, wiodący życie kontemplacyjne, jednak w łączności ze światem doczesnym: składający w intencji spraw świeckich ofiarę, modlący się, a jego siostra jako oznaka piękna, kwiat zdobiący zakonny wirydarz.

W przypadku kazania z okazji wieczystej profesji zakonnej pierwsze słowa tytułu kazania: „Quo vadis?” należy kojarzyć z ruchem. Odpowiedź na nie przynosi motto, również zwieńczone tymi słowami: „Vado ad eum, qui misit me, et nemo ex vobis interrogat me, quo vadis? Idę do tego, który mnie posłał, a żaden $\mathrm{z}$ was nie pyta mnie, gdzie idziesz?" (J 16,5). We wstępie kazania mówca osadza te słowa w szerszym kontekście Ewangelii Jana, wyprowadzając wniosek, iż Chrystus idzie ,[... [ nie na odpoczynek, ale na wszytkie przeciwności, na plac krwawy idzie" $\left(\mathrm{Q}, \mathrm{k} . \mathrm{B}_{2} \mathrm{v}\right)$. Słowa te Zbawiciel wypowiedział jeszcze przed pojmaniem, męką i śmiercią. Składającą śluby wieczyste zakonnicę ukazuje orator jako bohaterkę, która podąży za Mistrzem. Piskorski stawia tezę, iż wyruszająca śladem Chrystusa Szembekówna razem z przewodnikiem idzie złożyć „,całopalną ofiarę” ze swojego życia. Istotny kontekst wnoszą słowa Psalmu stanowiące propositio kazania: , Vota mea Domino reddam. Tibi sacrificabo hostiam. Tobie, Panie, oddam śluby moje. Tobie, ofiaro najświętsza, ofiarować będę ofiary moje" $\left(\mathrm{Q}, \mathrm{k} . \mathrm{B}_{2} \mathrm{v}\right)$. Wypełnienie ślubów tożsame jest ze złożeniem ofiary z siebie samej.

Celem dalszych rozważań jest udzielenie odpowiedzi na pytanie: „Quo vadis?”. Piskorski kreśli ideał życia zakonnego, pokazuje duchowy sens drogi. Nie ukrywa, iż będzie to peregrynacja wymagająca. Mówca odwołuje się do postawy Maryi, która podjęła się współcierpienia z Chrystusem podczas jego męki. Wzorem dla zakonnicy jest właśnie stojąca pod krzyżem Matka Boża. Piskorski w ramach comparatio doszukuje się metafizycznego podobieństwa między czterema żołnierzami, którzy mieli być wykonawcami wyroku na Chrystusie, a „czterema mocami”, jakie pozwoliły Maryi współcierpieć z konającym na krzyżu Synem:

Pierwsza moc była natura albo afekt macierzyński; druga gratia, to jest miłość, którą w niej łaska Ducha Świętego niewymowną wznieciła; trzecia sensus, zmysł, bo się wszytkiego tykała; czwarta ratio, rozum, bo godność Syna swego przenikała. Te cztery mocy ofiarą Bogu Ojcu Matkę Boską spólnie z Synem jego oddały (Q, k. B $)_{3}$.

\footnotetext{
${ }^{33}$ Zob. catholic-hierarchy.org, Bishop Mikołaj Oborski $\%$, http://www.catholic-hierarchy.org/ bishop/bobors.html [dostęp: $14 \mathrm{~V}$ 2021].

${ }^{34}$ Hasło: Oborski Mikołaj, [w:] Encyklopedia Krakowa, red. A.H. Stachowski, Warszawa-Kraków 2000, s. 680.
} 
Starając się odpowiedzieć na stawiane neoprofesce pytanie: „Quo vadis?”, Piskorski ustanawia analogię między drogą podjętą przez Maryję a tą, na jaką wkracza Franciszka. Postrzega ją jednak nieco inaczej niż współcierpiącą pod krzyżem Matkę. Kompilując cytaty z Eneidy oraz z Pieśni nad pieśniami, definiuje rolę zakonnicy: „Baranka niepokalanego i siostro, i oblubienico. Et soror, et coniunx. Soror mea sponsa" ${ }^{\prime 3}$. Jest ona dla Chrystusa zarazem siostrą, jak też oblubienicą - małżonką. Orator podkreśla, iż przewodniczką na drodze oddania się Bogu duszą i ciałem nie są święte patronki Klara i Teresa, lecz sama Maryja. Idąc tym tokiem rozumowania, ukazuje mówca analogię pomiędzy czterema mocami: „,Natura, gratia, sensus, ratio" $\left(\mathrm{Q}, \mathrm{k} . \mathrm{B}_{3} \mathrm{v}\right)$ a czterema cnotami - uosabianymi przez śluby zakonne. Opierając się na wspomnianej analogii, kaznodzieja wprowadza podział (divisio). Wiąże cnoty Maryi z treścią ślubów zakonnych i wskazuje ich odpowiedniki:

Klauzura prezentuje naturę, to jest jaśnie wielmożne w złotej wolności urodzenie twoje, w dobrowolnym więzieniu zamknięte; ubóstwo prezentuje gratiam, dostatki, honory świeckie, za niedostatek, za wyrzeczenie się wszytkiego zamienione; czystość Panu Bogu ślubna prezentuje sensum, ciało heroicznym poświęceniem się Bogu zwyciężone; posłuszeństwo prezentuje rozum woli starszych we wszytkim poddany $\left(\mathrm{Q}, \mathrm{k} . \mathrm{B}_{3} \mathrm{v}\right)$.

Poza rozważaniami poświęconymi ślubowi posłuszeństwa kolejne argumenty inicjuje pytanie: „Quo vadis?”. Odpowiadając na nie, Piskorski porównuje zakonnicę do ofiarnego baranka, który jest składany Bogu razem z Chrystusem. Kierując się Pieśnią nad pieśniami („Córko, przyciśnij do mnie jako sygnet serce twoje. Pone me ut signaculum super cor tuum", Pnp 8,6a; Q, k. $\mathrm{B}_{4}$ ), mówca zachęca, by zakonnica swym sercem przylgnęła do boskiego Oblubieńca. Uświadamia, że „zdrowie, uroda, szczęście, dostatki, honory” nie należą do człowieka, lecz są we władaniu Boga. Jedynym, czym człowiek dysponuje, jest wolna ludzka wola, umożliwiająca dokonywanie wyboru. Wywody na jej temat wiodą ku konkluzji, iż człowiek winien zachować wolną wolę wobec wszystkiego poza Bogiem. W tym względzie jako stworzenie musi podporządkować się Stwórcy, ,[...] aby się stał Bogu we wszytkim podobny” (Q, k. $\left.\mathrm{B}_{4}\right)$. Piskorski przechodzi od teorii do konkretu i przekonuje, zwracając się wprost do zakonnicy, że śluby zakonne pozwalają jej dostąpić łaski upodobnienia się do Boga: „[...] jako cnotą posłuszeństwa samemu Bogu podobną się stajesz?” $\left(\mathrm{Q}, \mathrm{k} . \mathrm{B}_{4}\right)$. Piskorski w ślad za Listem do Filipian akcentuje konieczność trwania w posłuszeństwie („Obediens usque ad mortem. Chcąc być posłuszną aż do

\footnotetext{
${ }^{35}$ „Ast ego, quae divom incedo regina, Iovisque / et soror et coniunx, una cum gente tot annos / bella gero!", cyt. za: Publius Vergilius Maro, Aeneidos, lib. I,45-46, 48, dostępne online: https:// www.thelatinlibrary.com/vergil/aen1.shtml [dostęp: 15 V 2021]; ,Ja, niebian pani, któram Jowisza jest siostrą / I żoną, z ludem jednym lat szereg niemały / Wojuję!”, cyt. za: Publiusz Wergiliusz Maro, Eneida, tłum. T. Karyłowski, oprac. S. Stabryła, wyd. 3, Wrocław 1981, s. 7. „Soror mea sponsa”, „Siostro ma, oblubienico” (Pnp 4,9).
} 
śmierci”, Flp 2,8; k. B ${ }_{4}$. Przekonuje, iż Szembekówna winna złożyć z siebie ofiarę w łączności z Matką Boską, niewolnicą Chrystusa, i akcentuje zarazem dobrowolność tego aktu.

Rozważania na temat ślubu ubóstwa również inicjuje pytanie „Quo vadis?”. Sięgając po liczne frazy biblijne, kaznodzieja przekonuje, iż także ubóstwo jest podstawową cnotą Chrystusa, bowiem ten z myślą o człowieku świadomie i dobrowolnie wyzbył się atrybutów boskości: „Chrystus, oddając się ofiarą Bogu Ojcu swemu, semet ipsum exinanivit, wyniszczył się ze wszytkiego. Będąc dostatnim wielce, dla nas ubogim stał się wielce [...]" (Flp 2,7; 2 Kor 8,9). Kolejne cytaty uświadomić mają Szembekównie, że rozpoczynając samodzielne życie w zakonie, pożegnać musi matkę i ojca, rodzeństwo, jak również splendory wnikające z przynależności do uprzywilejowanej warstwy społecznej. Ponownie uprzytamnia zakonnicy, iż ma ona stać się ofiarą Pańską. Za porzucone dobra będące domeną życia w świecie otrzymać ma, jak obiecuje kaznodzieja, nagrodę w niebie. Podsumowanie tego wątku stanowią słowa:

Nie chcę na ziemi, nie chcę Panie nic od ciebie inszego, tylko samego ciebie, Boże serca mego i cząstko moja, Boże mój na wieki. To moje nadzieje, to ozdoby, to dostatki, to przyjaźni, to ojciec, to matka, to brat, to siostra, Bóg serca mego, Bóg mój na wieki $\left(\mathrm{Q}, \mathrm{k} . \mathrm{B}_{4} \mathrm{v}\right)$.

Za pomocą paraleli ze ślubem ubóstwa wiąże mówca bohaterów biblijnych: bogacza (Łk 16,19-31) i mężną niewiastę (Prz 31,10-31). Bogacz doświadczył wiecznego potępienia, zaś niewiasta dostąpiła zbawienia. Piskorski koncentruje się na słowach o bisiorze i purpurze. Purpurę ukazuje jako symbol powagi i dostojeństwa, bisior jako znak cierpienia. Bogacz przywdział najpierw purpurę, potem bisior, natomiast niewiasta za życia doznawała utrapienia, by po śmierci otrzymać w nagrodę purpurę królewską. Wedle wykładni Piskorskiego składająca swe życie na ofiarę Bogu Szembekówna przywdziewa wybielony bisior tożsamy z ofiarą Chrystusa. Przyjmuje ona zaproszenie do mistycznego związku. Poświęcenie zakonnicy ma być odpowiedzią na ofiarę Oblubieńca: „Wyniszczył się dla mnie, a ja czemu nie mam stać się niczym, być ubóstwem, nie mieć nic własnego dla Zbawiciela mego" (Q, k. C).

Omawiając cnotę czystości (trzecią z kolei), dowodzi Piskorski, za listem św. Hieronima do Demetriadesa (Epistola ad Demetriadem de virginitate servan$d a$ ): „Assume scutum fidei, loricam iustitiae, galeam salutis, procede ad praelium; habet et pudicitia servata martyrium suum" $(\mathrm{Q}, \mathrm{k} . \mathrm{Cv})^{36}$, czyli - jak wyjaśnia dalej - zachowanie dziewictwa to forma męczeństwa: „Panno dziewico Bogu poślubiona, weźmij tarczą wiary, zbroję sprawiedliwości, szyszak zbawienia; spraw się, mężna Amazonko, przeciw nieprzyjaciołom twoim; ma i zachowany wstyd panieński męczeństwo swoje. Co panna, to męczennica, co lilija nieskażona, to palma,

\footnotetext{
${ }^{36}$ De virginitate opuscula sanctorum doctorum Ambrosii, Hieronymi et Augustini, apud Paulum Manutium, Aldi F., Romae 1562, s. 52.
} 
to laureola panieńskiej spólnie i męczeńskiej koronie naznaczona" $\left(\mathrm{Q}, \mathrm{k} . \mathrm{C}_{2}\right)$. Zachowanie czystości ma na celu współcierpienie z Chrystusem.

Szczególny związek dziewic z Barankiem wywodzi kaznodzieja z Apokalipsy św. Jana (Ap 13). Podążając za traktatem De sancta virginitate św. Augustyna i przekształcając pochodzące stamtąd zdanie: „Virginum gaudia sunt a caeterorum omnium gaudiorum sorte distincta" ${ }^{37}$, przekonuje, iż obcowanie z Barankiem jest dla panien źródłem szczególnej radości. Kaznodzieja dowodzi dalej, że dziewice są wyjątkowo predystynowane do tego, by iść za Barankiem: „Sequuntur agnum caeteri fideles ubique, praeterquam cum in decore virginitatis procedit" $(\mathrm{Q}, \mathrm{k} . \mathrm{Cv})^{38}$. Poza Apokalipsą i Pieśnią nad pieśniami powołuje się też na Psałterz (Ps 23).

Powracające niczym refren pytanie „Quo vadis?” inicjuje także ostatni argument, mówiący o „czwartej życia zakonnego fundamentalnej cnocie” (Q, k. $\left.\mathrm{C}_{2}\right)$, czyli klauzurze. Kaznodzieja dowodzi teologicznego sensu tego dobrowolnego więzienia przyjmowanego dla Chrystusa. Piskorski zauważa, iż Bóg działa mimo zamknięcia: poród Jezusa nie naruszył dziewictwa Maryi, wyszedł on z grobu, choć ten był zapieczętowany, wszedł do Wieczernika przez zamknięte drzwi. Miejscem zamknięcia zakonnicy ma być ogród ze źródłem, przez które rozumie Piskorski przebity bok Chrystusa. Nawiązuje więc do topiki klasztornego wirydarza. Utożsamia go z ludzkim sercem i rękami, które mają je dzierżyć. Odnosi się szczególnie do kultu Serca Jezusowego propagowanego przez wizytki.

Omówione argumenty wykorzystuje orator, by utwierdzić kandydatkę w dążeniu obraną drogą życia konsekrowanego. Stanowią one odpowiedź na inicjujące każde z nich pytanie: „Quo vadis?”.

Zmierzając do końca wywodu, wprowadza mówca motyw szczęśliwej zamiany. Jej genezy dopatruje się w postawie Jeftego, który poświęcił Bogu dziewictwo swej córki, zgodnie ze złożonym ślubem. Analogicznie Piskorski postrzega oddanie Maryi przez Jezusa Jana za syna. Kaznodzieja utożsamia złożenie Bogu ofiary z córki z otrzymaniem w zamian Chrystusa.

W zakończeniu kazania mowa o uzupełnieniu stroju zakonnego o elementy potwierdzające złożenie ślubów wieczystych. Teresa Franciszka otrzymuje bindę i velum (opaskę i welon). Wyszukując odesłań kulturowych do sytuacji związanych z poświęceniem córki przez ojca, wspomniał też Piskorski o ofierze złożonej bogom przez Agamemnona z Ifigenii. Króla greckiego utożsamia z Franciszkiem, zaś królewnę z córką Szembeka ${ }^{39}$. Dostrzega też podobieństwo sytuacji - wedle

${ }^{37}$ U Augustyna czytamy: „Ubi credo sunt gramina gaudia; non gaudia saeculi huius vana et insaniae mendaces, nec gaudia qualia in ipso regno Dei ceteris non virginibus erunt, sed a ceterorum omnium gaudiorum sorte distincta”, zob. Aurelius Augustinus, De Sancta Virginitate, Salisburgi 1845, cap. 27, s. 26-27.

${ }^{38}$ U Augustyna czytamy: „Sequantur itaque Agnum ceteri fideles, qui virginitatem corporis amiserunt, non quocumque ille ierit, sed quousque ipsi potuerint. Possunt autem ubique, praeter cum in decore virginitatis incedit", zob. ibidem, cap. 28, s. 27.

${ }^{39} \mathrm{~W}$ marginalium znajdujemy odesłanie do Eneidy, ks. 3 i słowa: „Ifigenia na ofiarę Dianie, alias księżycowi wydana od Agamemnona króla” $\left(\mathrm{Q}, \mathrm{k} . \mathrm{C}_{2} \mathrm{v}\right)$. 
kaznodziei poświęcona Bogu panna ma wesprzeć ojca swymi przebłagalnymi modlitwami zanoszonymi o zwycięstwo nad Turkami.

Zatem córka idzie za klauzurę, by stać się ofiarą dla Boga, męczenniczką dziewictwa, która w odosobnieniu czerpać będzie z wiecznie bijącego źródła, jakim jest przebity bok Chrystusa. Z biografii Teresy Szembekówny wynika, iż nie spędziła życia wyłącznie na osobistej modlitwie. Godna uwagi jest szeroka działalność, jaką prowadziła, pełniąc funkcje przełożonej klasztorów wizytek w Krakowie i w Wilnie. To za sprawą jej oddziaływania i powiązań rodzinnych papież Klemens XIII w 1765 r. zatwierdził kult Serca Jezusa w Królestwie Polskim ${ }^{40}$. Szembekówna dzięki swym dziełom przyczyniła się do rozpropagowania w Polsce tego kultu.

Piskorski opiera strukturę kazań o retoryczny schemat oracji ze wstępem, opowiadaniem, przedłożeniem, argumentacją i zakończeniem. W argumentatio drugiego z kazań wprowadził podział materii według czterech ślubów zakonnych. Strukturę łączy kaznodzieja z tematyką i symboliką wynikającą ze świętowanej okazji. Wiodącą rolę w tych duchownych oracjach odgrywa symbolika wywodząca się z Biblii, stanowiąca podbudowę dla metafizycznego sensu rozważań. Perswazja uprawiana przez Piskorskiego służy przekonaniu Teresy Franciszki o słuszności obranej drogi życiowej. Nie realizuje tego mówca, ukazując same dobre strony zakonnej egzystencji - podkreśla ofiarny charakter tej drogi, nieuchronność doświadczania cierpienia. Udostępnia środki mające ulżyć w trudnościach, pomóc w wytrwaniu. Stąd też paralela z cierpieniami Maryi i jej wytrwałością w znoszeniu bólu. Orator kreśli przed składającą profesję zakonną siostrą wizję drogi. Zamknięcie za klauzurą nie oznacza porzucenia życia aktywnego, koncentracji na kontemplowaniu Boga. Ukazuje dynamikę rzeczywistości obcowania ze Stwórcą w życiu doczesnym. W przypadku kazania prymicyjnego kaznodzieja koncentruje się na ofierze i na pokarmie. Fakt spożywania go przez Chrystusa po zmartwychwstaniu ma otworzyć nowego kapłana na mistyczny wymiar jego misji, na nowo zdefiniować miejsce w Kościele dzięki zaakcentowaniu ludzkich cech Jezusa. Pozwalają one uchwycić łączność między noszącym je boskim Zbawicielem i jego kapłanem-człowiekiem. Nowo wyświęcony duchowny świadomy cech ludzkich i boskich, jakie posiada Chrystus po zmartwychwstaniu, włączany jest w rzeczywistość nadprzyrodzoną, pozostając przy swym człowieczeństwie.

W nakreślonym obrazie nie zabrakło miejsca dla kwestii zasadniczych towarzyszących obrzędom przejścia, które inicjują życie duchowne kapłańskie i zakonne. Są nimi zwroty nie tylko do rozpoczynających drogę, lecz także do ich rodziców, rozważania na temat rezygnacji ze świeckiej drogi życiowej i związanych z nią apanaży, z jakich korzystali wysoko urodzeni.

Nie bez znaczenia jest literacka warstwa przekazu Piskorskiego. Opiera się on na Biblii, odwołuje do filozofii i teologii, sprawnie operuje słowem oraz znaczeniami. Płynnie przechodzi od porządku doczesnego do mistycznego, umiejętnie

\footnotetext{
${ }^{40}$ C. Drążek, Rozwój kultu Serca Jezusa w Polsce, op. cit., s. 89-91.
} 
posługuje się cytatami i konsekwentnie prowadzi wywód, pozostając w związku z myślą przewodnią każdego z kazań. Docenić należy umiejętność budowania konceptu łączącego myśl z czytań z danego dnia z okazją - święceniami, obłóczynami i profesją zakonną, zarazem syntetyczność przekazu i pogłębiony wykład na temat ofiary, dziewictwa, pokarmu i drogi.

\section{Bibliografia}

\section{Źródla}

Św. Augustyn, De doctrina christiana. O nauce chrześcijańskiej, wstęp i koment. J. Sulowski, Warszawa 1989.

Św. Augustyn, Wyznania, thum. S. Stabryła, Kraków 2020.

Aurelius Augustinus, De Sancta Virginitate, Salisburgi 1845.

Biblia w przektadzie księdza Jakuba Wujka z 1599 r., transkrypcja typu „B” oryginalnego tekstu z XVI w. i wstępy ks. J. Frankowski, wyd. 3, Warszawa 2000.

De virginitate opuscula sanctorum doctorum Ambrosii, Hieronymi et Augustini, apud Paulum Manutium, Aldi F., Romae 1562.

Dicta. Zbiór lacińskich sentencji, przystów, zwrotów, powiedzeń z indeksem osobowym i tematycznym, zebrał, oprac. i zred. C. Michalunio, Kraków 2005.

S. Piskorski, Basilicus iactus in primi lapidis positione..., Cracoviae 1666.

S. Piskorski, Quo vadis albo Kazanie przy profesyjej ślubów zakonnych Wielmożnej Jej Mości Panny Teresy z Stupowa Szembekówny, kasztelanki sanockiej, a teraz Wielebnej w Chrystusie Panu siostry Franciszki, w konwencie W[ielebnych] Panien Zakonnych Nawiedzenia Najświętszej Matki Boskiej przy Krakowie. W niedziele czwarta po Wielkiejnocy, Kraków 1686.

S. Piskorski, Wesole uraczenie Chrystusa. Sztuka ryby pieczonej i plastr miodu. Pierwsza ofiara Pańska W[ielebnego] Jego] M[ości] Ks[iędza] Michała z Stupowa Szembeka, kanonika przemyskiego, i przyjęciem habitu zakonnego W[ielmożnej] Jej M[o]ści Panny Teresy z Stupowa Szembekówny, kasztelan[iców] sanockich w klasztorze W[ielebnych] Panien Zakonnych Nawiedzenia Naświętszej Matki Boskiej przy Krakowie w dzień wtorkowy wielkanocny..., Kraków 1686.

Postylla polska, to jest lekcyje, epistoly i ewanjelije przez cały rok, Kraków 1577.

Publius Vergilius Maro, Aeneidos, lib. I, dostępne online: https://www.thelatinlibrary.com/vergil/ aen1.shtml [dostęp: 15 V 2021].

Publiusz Wergiliusz Maro, Eneida, thum. T. Karyłowski, oprac. S. Stabryła, wyd. 3, Wrocław 1981.

S. Twardowski, Władysław IV, król polski i szwedzki, wyd. R. Krzywy, Warszawa 2012 („Biblioteka Pisarzy Staropolskich", t. 40).

\section{Opracowania}

W. Baczkowska, Piskorski Sebastian Jan, [w:] Polski stownik biograficzny, t. 26, Wrocław 1981, s. 559.

M. Borkowska, Leksykon zakonnic polskich epoki przedrozbiorowej, t. 2: Polska Centralna i Potudniowa, Warszawa 2005.

Bractwo Kapłańskie Świętego Piotra. Duszpasterstwo wiernych Liturgii Łacińskiej. Polska, dostępne online: https://www.fssp.pl/articles/574 [dostęp: $10 \mathrm{~V}$ 2021]. 
Catholic-hierarchy.org, Bishop Mikołaj Oborski $\uparrow$, http://www.catholic-hierarchy.org/bishop/bobors. html [dostęp: 14 V 2021].

J. Daranowska-Łukaszewska, Szembekówna Teresa, [w:] Polski stownik biograficzny, t. 48, Warszawa-Kraków 2012-2013, s. 126.

K. Estreicher, Bibliografia polska, t. 24, Kraków 1912, s. 319-328.

R. Grześkowiak, J. Niedźwiedź, Nieznane polskie subskrypcje do emblematów religijnych Ottona van Veen i Hermana Hugona. Przyczynek do funkcjonowania zachodniej grafiki religijnej w kulturze staropolskiej, „Terminus” 2012, z. 1, s. 47-68.

J. Gwioździk, Kultura pisma i ksiązki w żeńskich klasztorach dawnej Rzeczypospolitej XVI-XVIII wieku, Katowice 2015.

Hasło: Oborski Mikołaj, [w:] Encyklopedia Krakowa, red. A.H. Stachowski, Warszawa-Kraków 2000, s. 680.

K. Kaczor-Scheitler, ,, Wieniec białoczerwony lilijowy...”. Staropolskie epitalamium nabożne Stanisława Teodora Piotrkowczyka, [w:] „Fons omnis honesti”. O literaturze w stużbie wartości: tradycja antyczna, kultura ziemiańska, encyklopedyzm i komunikacja. Studia ofiarowane Profesor Marii Wichowej w 70. rocznicę urodzin i 45. rocznice pracy naukowej i dydaktycznej, red. M. Kuran, Łódź 2020 („Analecta Literackie i Językowe”, t. 14), s. 181-197.

A. Kozak, Związki literacko-obrazowe w utworze S. Piskorskiego „Flores Vitae B. Salomeae”, [w:] Stowo i obraz. Materiały Sympozjum Komitetu Nauk o Sztuce Polskiej Akademii Nauk, Nieborów, 29 września - 1 października 1977 r., red. A. Morawińska, Warszawa 1982, s. $115-128$.

R. Krzywy, Pestańskie róże i równe szczęście. Rozważania na temat objaśnień do tekstu staropolskiego, „Terminus” 2007, z. 2(17), s. 123-140.

M. Kuran, Drukowane oracje na obłóczyny i profesje zakonne dominikanek lwowskich w XVIII w. adresatki, autorzy, walory literackie, funkcje spoteczne i kulturowe, [w:] ,, Arma nostrae militiae”. Kultura ksiażki i pisma Zakonu Kaznodziejskiego na ziemiach polskich, red. I. Pietrzkiewicz, M. Miławicki OP, Poznań 2019 („Studia i Źródła Dominikańskiego Instytutu Historycznego w Krakowie", t. 20), s. 313-334.

M. Kuran, Kazania upamiętniajace przyjęcie święceń duchownych przez synów i córki szlachty zwiazanej ze Wschowa (wybrane przykłady z rodzin Gurowskich i Mycielskich), [w:] Rycerze-szlachta-ziemianie. Szlachetnie urodzeni na ziemi wschowskiej i pograniczu wielkopolsko-śląskim, red. P. Klint, M. Małkus, K. Szymańska, Wschowa-Leszno 2014, s. 315-332.

M. Kuran, Kazanie na mszy prymicyjnej Józefa Bernarda Gurowskiego opata przemęckiego - ku chwale rodu, w stużbie ojczyźnie i Kościołowi, [w:] Reformacja i tolerancja. Jedność w różnorodności? Wspótistnienie różnych wyznań na ziemi wschowskiej i pograniczu wielkopolsko-śląskim, red. M. Małkus, K. Szymańska, Wschowa-Leszno 2015, s. 319-336.

M. Kuran, Konwencja pożegnania osoby zmarłej z żywymi w staropolskich kazaniach pogrzebowych - model i jego modyfikacje, [w:] Dawna i wspótczesna kultura funeralna, red. I. Steczko, R. Dźwigoł, Kraków 2018 („Dialog z Tradycją”, t. 6), s. 325-354.

M. Kuran, Tryumf Taidy ogłoszony. O diariuszu obłóczyn u dominikanek lwowskich księżnej Teofili Wiśniowieckiej w 1753 roku, „Tematy i Konteksty” 2014, nr 4(9): Piśmiennictwo zakonne, s. 269-291.

M. Kurzej, ,, Generosa proles Almae Parentis Sarmaticae”. Ryciny alegoryczne w zbiorach stemmatów ku czci nowych doktorów Uniwersytetu Jagiellońskiego, [w:] ,, Velis quod possis”. Studia z historii sztuki ofiarowane profesorowi Janowi Ostrowskiemu, red. A. Betlej et al., Kraków 2016, s. 303-309. 
M. Kurzej, Ksiądz Sebastian Piskorski a sztuka i historia, [w:] Sztuka po Trydencie, red. K. Kuczman, ks. A. Witko, Kraków 2014, s. 415-428.

A. Link-Lenczowski, Szembek Stanisław, [w:] Polski stownik biograficzny, t. 48, Warszawa-Kraków 2012-2013, s. 115-122.

B. Natoński SJ, Piskorski Sebastian, [w:] Słownik polskich teologów katolickich, red. H.E. Wyczawski, t. 3, Warszawa 1982, s. 373-374.

P. Nitecki, Biskupi Kościoła w Polsce w latach 965-1999. Stownik biograficzny, przedm. H. Gulbinowicz, Warszawa 2000.

T. Oracki, Stownik biograficzny Warmii, Prus Ksiązęcych i Ziemi Malborskiej od połowy XV do końca XVIII wieku, t. 2: L-Ż, Olsztyn 1988.

J. Pasiecznik, Kościół i klasztor reformatów w Krakowie, Kraków 1978.

J. Pelc, Stowo i obraz na pograniczu literatury i sztuk plastycznych, Kraków 2002.

B. Puchalska-Dąbrowska, Potrydencki ideał życia zakonnego na przykładzie staropolskich żywotów św. Teresy od Jezusa, „Rocznik Teologii Katolickiej” 2015, t. 14/1, s. 177-191.

Z. Ruta, Nauczyciele kolonii akademickich Uniwersytetu Krakowskiego w XVIII wieku, „Rocznik Naukowo-Dydaktyczny WSP w Krakowie" 1968, z. 32: Prace Historycznoliterackie 4, s. $95-167$.

M. Sokalski, Szembek Franciszek, [w:] Polski słownik biograficzny, t. 48, Warszawa-Kraków 2012-2013, s. 45.

B. Szady, Pratatury i kanonie Kolegiaty Wszystkich Świętych w Krakowie w II połowie XVIII wieku, „Archiwa, Biblioteki i Muzea Kościelne” 2006, t. 86, s. 331-354.

M. Trębska, ,Odważna Judyt” i mężna „,w Bogu Amazonka”, czyli o walce duchowej w staropolskich oracjach obłóczynowych, [w:] Wojny, bitwy, potyczki w kulturze staropolskiej, red. W. Pawlak, M. Piskała, Warszawa 2011, s. 373-386.

M. Trębska, Świeckie mowy obłóczynowe a ceremoniały zakonne w XVII wieku, „Napis” 2010, t. 1 (16), s. 123-137.

H. Wojtyska, Potrydenckie przemiany w koncepcji żeńskiego życia zakonnego, „Studia Warmińskie” 2001, t. 38, s. 179-184. 